\title{
Overview of Psychological Well-Being and Forgiveness of Christian Youth in North Sumatera
}

\author{
Pamela Hendra Heng, ${ }^{1 *}$ Desiree Gracia Nelwan, ${ }^{2}$ Septi Lathiifah ${ }^{3}$ \\ ${ }^{123}$ Universitas Tarumanagara, Indonesia \\ Email:pamelah@fpsi.untar.ac.id*
}

\begin{abstract}
The entire world is being attacked by a pandemic outbreak of Severe Acute Respiratory Syndrome Coronavirus 2 (SARS-CoV-2) or what we know as COVID-19. The Indonesian government policy of limiting the crowd of people when socializing affects various activities of young people at church, including in North Sumatera. This causes the psychological well-being (PWB) of the youth to be disturbed. Research shows Christian youths carry out activities such as wasting time on social media and online games that may lead to gambling (Jap et al., 2013) while neglecting their education, which is contrary to Christian teachings. Constantly pressured for neglecting responsibility and doing sins may affect PWB in youth, and forgiveness from God, their family and themselves may help increase PWB. Pre and post-test of PWB and forgiveness are administered. The instrument used is the PWB questionnaire based on Ryff's (1995) theory and TRIM-18 based on McCullough and Hoyt (2002). The subjects are adolescents and young adults aged 11-40 years in North Sumatera. Results show that both variables are high. There were differences based on participants' educational background and whether or not the participants read the bible everyday in the PWB post-test data. As for the forgiveness, results show that there were differences based on educational background and occupation in the pre-test data, while in the post-test data, there is a difference based on how many times an individual reads the bible in a day.
\end{abstract}

\section{Article History:}

Received : 23 Desember 2020

Accepted: 15 July 2021

Keywords:

psychological well-being;

forgiveness;

adolescents;

young adults.

\section{Introduction}

In the current situation where the whole world is overwhelmed by a pandemic outbreak of Severe Acute Respiratory Syndrome Coronavirus 2 (SARS-CoV-2) or known as COVID-19, the Christian youth in North Sumatra are also without exception experiencing various limitations to reduce the spread of COVID-19. The government's policy of limiting the number of people when socializing in groups has an impact on various activities of young people at church. ${ }^{1}$

${ }^{1}$ Comp. Imron Widjaja \& Lasmaria Nami Simanungkalit."Christian Religious Education Management, Government Service, In Cell Groups on The Quality of The Faith of Church Members In Indonesia Bethel Church Of Graha Pena." MAHABBAH: Journal of Religion and Education, Vol.l, No.l (2020): 55-69. 10.47135/mahabbah.vlil.8. 
A part of the developmental stage of adolescents is looking for self-identity and this often leads to low consideration regarding the current situation; various problems can arise in this stressful situation which greatly affects the social aspects that are needed by young people.

Research shows that the majority of Christian youth carry out activities that concern parents and church leaders including wasting their time on social media or playing online games that take up most of their time which correlated negatively to the time spent for school work. ${ }^{2}$ The games may be in a form of online gambling which is against the teachings of Christian beliefs. The gambling carried out by these youth are not in accordance with what is taught in the Bible, and so is considered a sin. Therefore, this relates to forgiveness as this situation forces Christian youth to ask forgiveness from God and also their parents for their bad manners and sins.

Psychological well-being (PWB) is when individuals feel fulfilled, can fully accept themselves, feel self-development, able see the meaning and purpose of life, can establish good relationships with others, are independent in decision making, as well as able to understand and control their environment. ${ }^{3}$ PWB has six dimensions, including a) autonomy, b) environmental mastery, c) personal growth, d) positive relations with others, e) purpose in life, and f) selfacceptance. $^{4}$

In addition, forgiveness has been shown to have a positive effect on well-being. ${ }^{5}$ Forgiveness is when the motivations for revenge and avoidance decreases, while the intention to be benevolent or do good increases. ${ }^{6}$ Forgiveness has three dimensions, namely (a) avoidance motivations, namely the desire to avoid people who hurt themselves; (b) revenge motivations refer to the desire to take revenge and the hope of harm to the person who hurt him; (c)

\footnotetext{
${ }^{2}$ Tjibeng Jap, Sri Tiatri, Edo S. Jaya, Mekar S. Suteja. "The Development of Indonesian Online Game Addiction Questionnaire." Plos One, Vol.8, No. 4 (April 2013): 1 - 5. https://doi.org/10.1371/journal.pone.0061098.

${ }^{3}$ Carol Diane Ryff, \& Corey Lee M. Keyes. "The structure of psychological well-being revisited," Journal of Personality and Social Psychology, Vol.64, No. 4 (November 1995): 719- 727, https://doi/10.1037/0022-3514.69.4.719.

${ }^{4}$ Carol Diane Ryff "Psychological Well-Being Revisited: Advances in The Science and Practice of Eudaimonia," Psychotherapy and Psychosomatics, Vol.83, (November 2014): 10-28. https://doi.org/10.1159/000353263.

${ }^{5}$ Everet L. Worthington, Charlotte van Oyen Witvliet, Pietro Pietrini, and Andrea J. Miller "Forgiveness, Health, and Well-Being: A Review of Evidence for Emotional Versus Decisional Forgiveness, Dispositional Forgivingness, and Reduced Unforgiveness." Journal of Behavioral Medicine, Vol.30, No. 4 (September 2007): 291302. http://eresources.perpusnas.go.id:2083/login.aspx?direct=true $\& d b=c m e d m \& A N=17453329 \&$ site=eds-live; Sri Wahyuni \& Yan Kristianus Kadang. "Mendidik Anak (Educating Children)". 2UAERENS: Journal of Theology and Christianity Studies, Vol.1, No.2 (December 2, 2019): 122-143. Accessed October 9, 2021. https://jurnal.widyaagape.ac.id/index.php/quaerens/article/view/6.

${ }^{6}$ Michael E. McCullough \& Giacomo Bono "Positive Responses to Benefit and Harm: Bringing Forgiveness and Gratitude into Cognitive Psychotherapy." Journal of Cognitive Psychotherapy: An International Quarterly, Vol.20, No.2 (June 2006): 1 - 10. https://doi.org/10.1891/088983906780639835.
} 
benevolence motivations, is an increase in the urge to behave positively, or act kindly to people who have hurt them. ${ }^{7}$ Research by Bono et al. stated that forgiveness can be associated with increased mental health, physical health, self-esteem, well-being, and life satisfaction. ${ }^{8}$ Forgiveness comes from a basic act of humanity, or you could say solidarity is impossible. Forgiveness is an act that is based on love. Love given by God. Forgiveness is often an inspiration, and at the same time it can change human nature. ${ }^{9}$ Several other research results support a significant positive relationship between forgiveness and psychological well-being in different subjects. ${ }^{10}$

\section{Method}

This research design is non-experimental quantitative, using a measuring instrument in the form of a questionnaire. Participants in this study are adolescents and young adults aged 11 to 40 years. Religion, education level, gender, occupation, and domicile are not limited. The number of participants obtained was 57 people. The sampling technique in this study is convenient sampling, which means that the participants were obtained based on the availability and willingness to fill out the questionnaire.

This research was conducted online on December 4, 2020 in Jakarta. The speakers resided in Jakarta while the participants were in North Sumatera. This study consists of 2 stages, namely a) distributing the pre-test questionnaire link and b) distributing the post-test questionnaire link, both of which include participants' identity information, as well as questionnaires for PWB and forgiveness.

The research instruments used consist of a) a questionnaire that includes simple questions about the participant's identity and b) a measuring tool for Psychological Well-Being

\footnotetext{
${ }^{7}$ McCullough, M. E \& Hoyt, W. T. "Transgression-Related Motivational Dispositions: Personality substrates of forgiveness and their links to the big five". Personality and Social Psychology Bulletin, No. 28 (2002) 15561573. https://doi.org/10.1177/014616702237583.

${ }^{8}$ Giacomo Bono, Michael. E. McCullough, Lindsay. M. Root "Forgiveness, Feeling Connected to Others, and Well-Being: Two Longitudinal Studies." Personality and Social Psychology Bulletin, Vol.34, No. 2 (March 2008): 182195. https://doi.org/10.1177/0146167207310025.

${ }^{9}$ Siregar Jundo Parasian. "Pengembangan Watak Kristen Melalui Pengampunan". Jurnal Teologi dan Pendidikan Kristen, No.1 (2020): 33-42. https://doi.org/10.46305/im.vlil.5.

${ }^{10}$ Raudatussalamah., \& Reni Susanti. "Pemaafan (forgiveness) dan Psychological Wellbeing pada Narapidana Wanita." Marwah Vol.8, No.2 (December 2014): 219-234. http://dx.doi.org/10.24014/marwah.vl3i2.890; Vita Ratna Juwita, \& Erin Ratna Kustanti. "Hubungan antara Pemaafan dengan Kesejahteraan Psikologis pada Korban Perundungan.” Jurnal Empati, Vol.7, No. 1 (Maret 2018): 274-282. https://ejournal3.undip.ac.id/index.php/empati/article/view/20196.
} 
from Tarumanagara University's Psychological Research and Measurement Department, and c) a measuring tool for forgiveness, namely the Transgression Related Interpersonal Motivations Inventory (TRIM-18).

PWB measuring instrument is a 5 likert-scale. and has six dimensions and 31 items; The six dimensions measured are (a) autonomy, (b) personal growth, (c) environmental mastery, (d) self-acceptance, (e) purpose in life, and (f) positive relations with others. While TRIM-18 is also a 5 likert-scale, with three dimensions and 18 items. The three dimensions measured are (a) revenge motivations, (b) avoidance motivations, and (c) benevolence motivations.

The authors discussed the topics to be discussed in Community Service activities (PKM), then the committee looked for existing phenomena. Communication with partners related to PKM activities is carried out by the PKM chairman. After the agreement between the two parties, the committee began to prepare all preparations. Starting from making the required correspondence, activity proposals, activity posters, and materials needed. Activity posters were given to the partners for the first time, then the committee distributed the activity posters on several social media. Before the activity started, the committee distributed a google form link which was distributed to participants. The link is used for registration and pre-test related to the psychological well-being questionnaire and TRIM-18. After participants fill in the link, participants will be directed to a WhatsApp Group (WAG) as a media to provide information about the activity. The total number of participants who registered was 115 people.

The activity was attended by 78 participants. Participants were given an understanding of psychological well-being and forgiveness for Christian youths in the North Sumatra region. After data was obtained, an evaluation link was given which includes participant personal data, post-test PWB and forgiveness questionnaires, and evaluation of activities. The total number of participants who filled in the evaluation link was 66 people. Of the 66 people, only 57 people can be processed as data. The committee processed the data to see an overview of PWB and forgiveness among Christian youths in the North Sumatra region; As well as comparing the pretest and post-test data.

Data processing in this study was carried out by descriptive analysis to obtain a comprehensive overview of psychological well-being and forgiveness in adolescents and young adults. Normality testing used One Sample Kolmogorov-Smirnov, and to test differences in data authors used One-Way ANOVA, Independent Sample T-Test and Paired Sample T-Test. Data processing used Statistical Package for the Social Sciences (SPSS) version 21. 


\section{Result and Discussion}

\section{Result}

The total data processed was 57 participants. There were 2 participants from HA with a percentage of $3.5 \%$, participants from $\mathrm{HB}$, amounting to 6 people with a percentage of $10.5 \%$, participants from HC totaled 15 people with a percentage of $26.3 \%$ and participants who came from HD totaled 34 people with a percentage of $59.6 \%$. The complete data can be seen in table 1 .

Table 1. Overview of Participants Based on Churches

\begin{tabular}{|c|c|c|}
\hline Church & Frequency & Percentage \\
\hline $\mathrm{HA}$ & 2 & 3.5 \\
\hline $\mathrm{HB}$ & 6 & 10.5 \\
\hline $\mathrm{HC}$ & 15 & 26.3 \\
\hline $\mathrm{HD}$ & 34 & 59.6 \\
\hline Total & 57 & 100.0 \\
\hline
\end{tabular}

Next, based on the data obtained, participants who are under 20-40 years old are 55 people with a percentage of $96.5 \%$ and participants who are 20-40 years old are 2 people with a percentage of $3.5 \%$. This can be seen in table 2 .

Table 2. Overview of Participants Based on Age

\begin{tabular}{|c|c|c|}
\hline Age Range & Frequency & Percentage \\
\hline Under $20-40$ Years Old & 55 & 96.5 \\
\hline $20-40$ Years Old & 2 & 3.5 \\
\hline Total & 57 & 100.0 \\
\hline
\end{tabular}

Data based on gender shows that there are 19 male participants with a percentage of $33.3 \%$ and there are 38 female participants with a percentage of $66.7 \%$. This can be seen in table 3.

Table 3. Overview of Participants Based on Gender

\begin{tabular}{|c|c|c|}
\hline Gender & Frequency & Percentage \\
\hline Male & 19 & 33.3 \\
\hline Female & 38 & 66.7 \\
\hline Total & 57 & 100.0 \\
\hline
\end{tabular}


Based on the data obtained, participants with a background of junior high school education are 18 people (31.6\%), 37 people (64.9\%) have a senior high school education background, 1 person (1.8\%) with a diploma education background and 1 person (1.8\%) with a bachelor's degree. This can be seen in table 4 .

Table 4. Overview of Participants Based on Educational Background

\begin{tabular}{|c|c|c|}
\hline Educational Background & Frequency & Percentage \\
\hline Junior High School & 18 & 31.6 \\
\hline Senior High School & 37 & 64.9 \\
\hline Diploma & 1 & 1.8 \\
\hline Bachelor's Degree & 1 & 1.8 \\
\hline Total & 57 & 100.0 \\
\hline
\end{tabular}

Next, based on occupation, 50 people are students with a percentage of $87.7 \%, 6$ participants are undergraduate students with a percentage of $10.5 \%$, and $1(1.8 \%)$ person is categorized as having another job other than the ones listed.

Table 5. Overview of Participants Based on Occupation

\begin{tabular}{|c|c|c|}
\hline Occupation & Frequency & Percentage \\
\hline Student & 50 & 87.7 \\
\hline College Student & 6 & 10.5 \\
\hline Others & 1 & 1.8 \\
\hline Total & 57 & 100.0 \\
\hline
\end{tabular}

Based on the data obtained, there are 16 participants who read the bible every day with a percentage of $28.1 \%$, and the participants who do not read the bible every day are 41 people with a percentage of $71.9 \%$. Complete data regarding participants' daily Bible reading can be seen in table 6.

Tabel 6. Overview of Participants Based on Daily Bible Reading

\begin{tabular}{|c|c|c|}
\hline Read Bible & Frequency & Percentage \\
\hline Yes & 16 & 28.1 \\
\hline No & 41 & 71.9 \\
\hline Total & 57 & 100.0 \\
\hline
\end{tabular}


Based on the data obtained, the number of participants who prayed every day are 56 people with a percentage of $98.2 \%$, and 1 participant do not pray every day with a percentage of $1.8 \%$. Complete data regarding the participants' daily prayer can be seen in table 7 .

Table 7. Overview of Participants Based on Praying Daily

\begin{tabular}{|c|c|c|}
\hline Pray Daily & Frequency & Percentage \\
\hline Yes & 56 & 98.2 \\
\hline No & 1 & 1.8 \\
\hline Total & 57 & 100.0 \\
\hline
\end{tabular}

Based on the data obtained, participants who read the bible and pray individually are 51 people with a percentage of $89.5 \%$, and participants who read the bible and pray in groups are 6 people with a percentage of $10.5 \%$. Complete data on how participants read the bible and pray can be seen in table 8 .

Table 8. Overview of Participants Based on How to Read the Bible and Pray

\begin{tabular}{|c|c|c|}
\hline How to Read the Bible and Pray & Frequency & Percentage \\
\hline Individually & 51 & 89.5 \\
\hline In groups & 6 & 10.5 \\
\hline Total & 57 & 100.0 \\
\hline
\end{tabular}

Based on the data obtained, participants who use social media for less than 2 hours are 6 people with a percentage of $10.5 \%$, participants who use social media for 2 - 4 hours are 16 people with a percentage of $28.1 \%$ and participants who use social media for more than 4 hours are 35 people with a percentage of $61.4 \%$. Complete data regarding participants' duration of using social media can be seen in table 9.

Table 9. Overview of Participants Based on Durating Using Social Media

\begin{tabular}{|l|l|l|}
\hline Duration & Frequency & Percentage \\
\hline Less than 2 hours & 6 & 10.5 \\
\hline $2-4$ hours & 16 & 28.1 \\
\hline More than 4 hours & 35 & 61.4 \\
\hline Total & 57 & 100.0 \\
\hline
\end{tabular}


The normality test used in this study is the One-Sample Kolmogorov-Smirnov normality test. The normality test of the total score of the psychological well-being and forgiveness questionnaire shows that the data distribution is normal. Distribution is considered normal if the distribution value, namely the $\mathrm{p}$ value is greater than 0.05 . The total score data for the psychological well-being questionnaire had a value of $\mathrm{p}=0.227$ (p>0.05) and the data for the total forgiveness score had a value of $\mathrm{p}=0.998(\mathrm{p}>0.05)$.

The next section will explain the overview of psychological well-being among Christian youths in the North Sumatra region. For the PWB questionnaire, the researcher used a measuring instrument with 31 items using a scale of $1-5$, with a hypothetical mean of 3 . The empirical mean for PWB obtained in the pre-test is 3.4361 in the post-test is 3.2891. These results indicate that the mean empirical score is greater than the hypothetical; the participants' psychological well-being is high.

The data overview of the first dimension, autonomy, has an empirical mean of 3.1404 in the pre-test, and 2.8246 in the post-test. The empirical mean score in the pre-test is high and empirical mean score in the post-test is low. This also means that the PWB on the participant's autonomy dimension decreased. Furthermore, the data description in the second dimension, namely personal growth, has an empirical mean of 3.9333 in the pre-test and 3.4947 in the posttest; participants' personal growth dimensions is high.

The data overview of the third dimension, purpose in life, has an empirical mean of pretest of 3.5915 and 3.1479 in the empirical mean of post-test is 3.1479. The empirical mean score obtained was higher than the hypothetical mean score, which means that the psychological well-being on the participant's dimension of purpose in life was high. Then in the fourth dimension, the empirical mean in the pre-test is 3.7333 and the empirical mean in the post-test is 3.3158; participant's self-acceptance dimension is high.

The data overview of the fifth dimension, namely environmental mastery, has an empirical mean of 2.9605 in the pre-test and 3.3728 in the post-test which means that participants' environmental mastery increases. In the last dimension, positive relation with others, has an empirical mean of 3.2573 in the pre-test and an empirical mean of 3.5789 in the post-test. The empirical mean of positive relations with others dimension is high. Complete data regarding the description of psychological well-being can be seen in table 10 . 
Table 10. Empirical Mean of PWB

\begin{tabular}{|c|c|c|}
\hline \multicolumn{1}{|c|}{ Dimension } & Hypothetical Mean & Empirical Mean \\
\hline Pre-Test PWB & 3 & 3.4361 \\
\hline Autonomy & 3 & 3.1404 \\
\hline Personal Growth & 3 & 3.9333 \\
\hline Purpose in Life & 3 & 3.5915 \\
\hline Self-Acceptance & 3 & 3.7333 \\
\hline Environmental Mastery & 3 & 2.9605 \\
\hline Positive Relation with Other & 3 & 3.2573 \\
\hline Post-Test PWB & 3 & 3.2891 \\
\hline Autonomy & 3 & 2.8246 \\
\hline Personal Growth & 3 & 3.4947 \\
\hline Purpose in Life & 3 & 3.1479 \\
\hline Self-Acceptance & 3 & 3.3158 \\
\hline Environmental Mastery & 3 & 3.3728 \\
\hline Positive Relation with Other & 3 & 3.5789 \\
\hline
\end{tabular}

The next section will explain the overview of forgiveness of Christian youth in the North Sumatra region. To measure forgiveness, the researchers used Transgression Related Interpersonal Motivations Inventory (TRIM-18) consisting of 18 items using a scale of $1-5$, with a hypothetical mean of 3. The empirical mean obtained in the pre-test is 2.2816 and in the posttest is 2.2734. These results indicate that the mean empirical score is greater than the hypothetical mean which means that the participants' forgiveness is high.

The data overview of the first dimension, namely avoidance motivation, has a hypothetical mean of 3, while the pre-test's empirical mean is 2.2381 and the post-test's empirical mean is 2.3158; participants' avoidance motivation is high. Next, the data overview in the second dimension, namely revenge motivation, has an empirical mean of 1.8728 in the pretest and the empirical mean of 1.7675 in the post-test. The empirical mean score obtained was higher than the hypothetical mean score, which means that participants' revenge motivation is high. Last, the data in the third dimension, namely benevolence motivation, has an empirical 
mean in the pre-test is 2.7339 and the empirical mean in the post-test is 2.7368 . The empirical mean score obtained is higher than the hypothetical mean score, which means that benevolence motivation in participant is high. Complete data regarding the overview of forgiveness can be seen in table 11.

Table 11. Empirical Mean of Forgiveness

\begin{tabular}{|c|c|c|}
\hline Dimensi & Hypothetical Mean & Empirical Mean \\
\hline Pre-Test Forgiveness & 3 & 2.2816 \\
\hline Avoidance Motivation & 3 & 2.2381 \\
\hline Revenge Motivation & 3 & 1.8728 \\
\hline Benevolence Motivation & 3 & 2.7339 \\
\hline Post-Test Forgiveness & 3 & 2.2734 \\
\hline Avoidance Motivation & 3 & 2.3158 \\
\hline Revenge Motivation & 3 & 1.7675 \\
\hline Benevolence Motivation & 3 & 2.7368 \\
\hline
\end{tabular}

Result obtained based on the Paired Sample T-Test show that the pre-test and the post-test of PWB is $\mathrm{t}(3.859)=0.000(\mathrm{p}<0.05)$ which means that there is a difference between both tests. Meanwhile, the result of forgiveness' pre-test and post-test is $t(0.189)=0.850(p>0.05)$, which means that there is no difference between the pre-test and post-test results. Complete data regarding the comparison of PWB and forgiveness can be seen in table 12.

Table 12. Comparison of Psychological Well-Being and Forgiveness

\begin{tabular}{|l|c|c|}
\hline \multicolumn{1}{|c|}{ Variables } & $\mathrm{t}$ & $\mathrm{p}$ \\
\hline Psychological Well-Being & 3.859 & 0.000 \\
\hline Forgiveness & 0.189 & 0.850 \\
\hline
\end{tabular}

Based on the One Way ANOVA analysis, PWB pre-test found $F(1.042)=0.382>0.05$ and PWB post-test found $F(1.561)=0.210>0.05$; Psycholoical well-being of Christian youth in the North Sumatra region showed no difference towards the origin of the church both in the pretest and post-test. Complete data on psychological well-being based on churches can be seen in table 13. 
Table 13. PWB Based on Churches

\begin{tabular}{|l|c|c|}
\hline & F & $\mathrm{p}$ \\
\hline Pre-Test & 1.042 & 0.382 \\
\hline Post-Test & 1.561 & 0.210 \\
\hline
\end{tabular}

Based on the analysis with One Way ANOVA, the forgiveness pre-test is known to be $\mathrm{F}(1.106)=0.355>0.05$ and the forgiveness post-test is known to be $\mathrm{F}(0.688)=0.564>0.05$ Forgiveness of Christian youth in the North Sumatra region shows no difference to the origin of the churches both in the pre-test and post-test. The complete data can be seen in table 14 .

Table 14. Forgiveness Based on Churches

\begin{tabular}{|l|c|c|}
\hline & F & P \\
\hline Pre-Test & 1.106 & 0.355 \\
\hline Post-Test & 0.688 & 0.564 \\
\hline
\end{tabular}

Based on Levene's test for equality of variances, the pre-test data value is $F(0.323)=0.572$ $(p>0.05)$. Therefore, the difference test will refer to the equal variances assumed. Independent sample $\mathrm{t}$-test was conducted to test the $\mathrm{F}$ value to determine the similarities or differences in variance between participants who were under 20 years of age and 20 - 40 years old in the pretest. The results are based on $\mathrm{p}$ from the $\mathrm{F}$ value that is greater than .05 , then $\mathrm{t}(-0.862)=0.393$; $\mathrm{p}>0.05$. Meanwhile, the post-test data value was $\mathrm{F}(0.001)=0.972(\mathrm{p}>0.05)$. Therefore, the difference test will refer to the equal variances assumed.

Independent sample $t$-test was conducted to test the $\mathrm{F}$ value to determine the similarities or differences in variance between participants who were under 20 years of age and 20 - 40 years. The results are based on $p$ from an $F$ value that is greater than .05 , then $t(-1.534)=$ $0.131 ; \mathrm{p}>0.05$. This indicates that there is no difference in psychological well-being among Christian youth in North Sumatra based on age, both on the pre-test and post-test. Complete data regarding different psychological well-being tests based on age can be seen in table 15 .

Table 15. PWB Based on Age

\begin{tabular}{|l|c|c|c|c|}
\hline & F & P & T & $\mathrm{p}$ \\
\hline Pre-Test & 0.323 & 0.572 & -0.862 & 0.393 \\
\hline Post-Test & 0.001 & 0.972 & -1.534 & 0.131 \\
\hline
\end{tabular}


In Levene's test for equality of variances, it appears that the pre-test data value is $F$ $(2.908)=0.094$ ( $>0.05)$. Therefore, the difference test will refer to the equal variances assumed. Independent sample $\mathrm{t}$-test was conducted to test the $\mathrm{F}$ value to determine the similarities or differences in variance between participants who were under 20 years of age and 20-40 years old in the pre-test. The results are based on $\mathrm{p}$ from an $\mathrm{F}$ value greater than .05 , then $\mathrm{t}(.738)=0.088 ; \mathrm{p}$ $>0.05$. Meanwhile, the post-test data value was $F(0.088)=0.768(\mathrm{p}>0.05)$. Therefore, the difference test will refer to the equal variances assumed.

Independent sample $\mathrm{t}$-test was conducted to test the $\mathrm{F}$ value to determine the similarities or differences in variance between participants who were under 20 years of age and 20 - 40 years. The results are based on $\mathrm{p}$ from the $\mathrm{F}$ value greater than .05 , then $\mathrm{t}(1.246)=0.218$; p > 0.05. This shows that there is no difference in forgiveness among Christian youth in the North Sumatra region based on age in both the pre-test and post-test. Complete data regarding the different forgiveness tests based on age can be seen in table 16.

Table 16. Forgiveness Based on Age

\begin{tabular}{|l|c|c|c|c|}
\hline & $\mathrm{F}$ & $\mathrm{p}$ & $\mathrm{t}$ & $\mathrm{p}$ \\
\hline Pre-Test & 2.908 & 0.094 & 1.738 & 0.088 \\
\hline Post-Test & 0.088 & 0.768 & 1.246 & 0.218 \\
\hline
\end{tabular}

In Levene's test for equality of variances, it appears that the pre-test data value is $F$ $(0.021)=0.884(p>0.05)$. Therefore, the difference test will refer to the equal variances assumed. Independent sample t-test was conducted to test the $\mathrm{F}$ value in order to determine the similarities or differences in variance between male and female participants. The results are based on $\mathrm{p}$ from the $\mathrm{F}$ value that is greater than .05 , then $\mathrm{t}(-1.197)=0.236 ; \mathrm{p}>0.05$. Meanwhile, the post-test data value was $\mathrm{F}(0.388)=0.536(\mathrm{p}>0.05)$. Therefore, the difference test will refer to the equal variances assumed.

Independent sample $\mathrm{t}$-test was conducted to test the $\mathrm{F}$ value in order to determine the similarities or differences in variance between male and female participants. The results are based on $\mathrm{p}$ from the $\mathrm{F}$ value that is greater than .05 , then $\mathrm{t}(-0.623)=0.536 ; \mathrm{p}>0.05$. This indicates that there is no difference in psychological well-being among Christian youths in North Sumatra based on gender in both the pre-test and post-test. Complete data regarding different psychological well-being tests based on gender can be seen in table 17 . 
Table 17. PWB Based on Gender

\begin{tabular}{|l|c|c|c|c|}
\hline & $\mathrm{F}$ & $\mathrm{P}$ & $\mathrm{t}$ & $\mathrm{P}$ \\
\hline Pre-Test & 0.021 & 0.884 & -1.197 & 0.236 \\
\hline Post-Test & 0.388 & 0.536 & -0.623 & 0.536 \\
\hline
\end{tabular}

In Levene's test for equality of variances, it appears that the pre-test data value is $F(0.626)=0.432(p>0.05)$. Therefore, the difference test will refer to the equal variances assumed. Independent sample $t$-test was conducted to test the $F$ value in order to determine the similarities or differences in variance between male and female participants. The results are based on $\mathrm{p}$ from an F value greater than .05 , then $\mathrm{t}(0.543)=0.590 ; \mathrm{p}>0.05$. Meanwhile, the posttest data value was $F(0.363)=0.549(p>0.05)$. Therefore, the difference test will refer to the equal variances assumed.

Independent sample $\mathrm{t}$-test was conducted to test the $\mathrm{F}$ value in order to determine the similarities or differences in variance between male and female participants. The results are based on $\mathrm{p}$ from the $\mathrm{F}$ value that is greater than .05 , then $\mathrm{t}(1.646)=0.105 ; \mathrm{p}>0.05$. This shows that there is no difference in forgiveness among Christian youth in the North Sumatra region based on gender in both the pre-test and post-test. Complete data regarding the Forgiveness difference test based on gender can be seen in table 18 .

Tabel 18. Forgiveness Based on Gender

\begin{tabular}{|l|c|c|c|c|}
\hline & $\mathrm{F}$ & $\mathrm{P}$ & $\mathrm{t}$ & $\mathrm{p}$ \\
\hline Pre-Test & 0.626 & 0.432 & 0.543 & 0.590 \\
\hline Post-Test & 0.363 & 0.549 & 1.646 & 0.105 \\
\hline
\end{tabular}

Based on the One Way ANOVA analysis, the PWB pre-test is known to be $F(1.620)=$ $0.196>0.05$ and the PWB post-test is known to be $\mathrm{F}(3.944)=0.013<0.05$. which means the psychological well-being of Christian youth in the North Sumatra region did not show any differences based on education in the pre-test, but there were differences in the post-test. Complete data on psychological well-being based on education can be seen in table 19.

Table 19. PWB Based on Educational Background

\begin{tabular}{|l|c|c|}
\hline & F & P \\
\hline Pre-Test & 1.620 & 0.196 \\
\hline Post-Test & 3.944 & 0.013 \\
\hline
\end{tabular}


Based on the analysis with One Way ANOVA, the forgiveness pre-test is known to be $F(3.573)=0.020<0.05$ and the forgiveness post-test is known to be $F(1.128)=0.346>0.05$. which means the forgiveness of Christian youth in the North Sumatra region shows a difference based on education in the pre-test, but there is no difference in the post-test. The complete data based on education can be seen in table 20 .

Table 20. Forgiveness Based on Educational Background

\begin{tabular}{|l|c|c|}
\hline & F & P \\
\hline Pre-Test & 3.573 & 0.020 \\
\hline Post-Test & 1.128 & 0.346 \\
\hline
\end{tabular}

Based on the One Way ANOVA analysis, the PWB pre-test is known to be $F(1.385)=$ $0.259>0.05$ and the PWB post-test is known to be $F(1.898), p=0.160>0.05$. which means the psychological well-being of Christian youth in the North Sumatra region does not show any differences based on occupation on the pre-test or post-test. Complete data on psychological well-being based on work can be seen in table 21 .

Table 21. PWB Based on Occupation

\begin{tabular}{|l|c|c|}
\hline & F & P \\
\hline Pre-Test & 1.385 & 0.259 \\
\hline Post-Test & 1.898 & 0.160 \\
\hline
\end{tabular}

Based on the analysis with One Way ANOVA, the forgiveness pre-test was found to be $F(3.858)=0.027<0.05$ and the forgiveness post-test was found to be $F(1.699)=0.193>0.05$. which means the forgiveness of Christian youth in the North Sumatra region shows differences based on occupation in the pre-test, but there is no difference in the post-test. The complete data based on work can be seen in table 22.

Table 22. Forgiveness Based on Occupation

\begin{tabular}{|l|c|c|}
\hline & F & P \\
\hline Pre-Test & 3.858 & 0.027 \\
\hline Post-Test & 1.699 & 0.193 \\
\hline
\end{tabular}

In Levene's test for equality of variances, it appears that the pre-test data value is $\mathrm{F}$ $(0.540)=0.465(p>0.05)$. Therefore, the difference test will refer to the equal variances assumed. 
The independent sample $t$-test was conducted to test the F value in order to determine the similarities or differences in variance between participants who read the Bible every day. The results are based on $\mathrm{p}$ from the $\mathrm{F}$ value greater than .05 then $\mathrm{t}(1.626)=0.110 ; \mathrm{p}>0.05$. Meanwhile, the post-test data value is $F(4.094)=0.048(\mathrm{p}<0.05)$.

This shows that there is no difference in psychological well-being among Christian youths in the North Sumatra region based on reading the bible every day on the pre-test, but there are differences in the post-test. test. Complete data regarding different psychological wellbeing tests based on reading the Bible every day can be seen in table 23 .

Table 23. PWB Based on Daily Bible Reading

\begin{tabular}{|l|c|c|c|c|}
\hline & $\mathrm{F}$ & $\mathrm{P}$ & $\mathrm{t}$ & $\mathrm{p}$ \\
\hline Pre-Test & 0.540 & 0.465 & 1.626 & 0.110 \\
\hline Post-Test & 4.094 & 0.048 & & \\
\hline
\end{tabular}

In Levene's test for equality of variances, it appears that the pre-test data value is $F$ $(0.021)=0.887(p>0.05)$. Therefore, the difference test will refer to the equal variances assumed. The independent sample $t$-test was conducted to test the $F$ value in order to determine the similarities or differences in variance between participants who read the Bible every day. The results are based on $\mathrm{p}$ from an $\mathrm{F}$ value that is greater than .05 , then $\mathrm{t}(-1.686)=0.097 ; \mathrm{p}>0.05$. Meanwhile, the value of the post-test data was $F(0.001)=0.982(p>0.05)$. Therefore, the difference test will refer to the equal variances assumed.

The independent sample $\mathrm{t}$-test was conducted to test the $\mathrm{F}$ value in order to determine the similarities or differences in variance between participants who read the Bible every day. The results are based on $\mathrm{p}$ from an $\mathrm{F}$ value greater than .05 , then $\mathrm{t}(-2.267)=0.027 ; \mathrm{p}<0.05$. This shows that there is no difference in forgiveness among Christian youths in the North Sumatra region based on reading the Bible every day in the pre-test, but there is a difference in the posttest. Complete data regarding the different test for forgiveness based on reading the Bible every day can be seen in table 24 .

Table 24. Forgiveness Based on Daily Bible Reading

\begin{tabular}{|l|c|c|c|c|}
\hline & $\mathrm{F}$ & $\mathrm{P}$ & $\mathrm{t}$ & $\mathrm{p}$ \\
\hline Pre-Test & 0.021 & 0.887 & -1.686 & 0.097 \\
\hline Post-Test & 0.001 & 0.982 & -2.267 & 0.027 \\
\hline
\end{tabular}


In Levene's test for equality of variances, it appears that the pre-test data value which refers to the equal variances assumed independent sample $t$-test to find out the similarities or differences in variance between participants who pray every day is $t(0.349)=0.728 ; p>0.05$. Meanwhile, the post-test data value which refers to the equal variances assumed independent sample $t$-test to find out the similarities or differences in variance between participants who pray every day is $t(0.274)=0.785 ; \mathrm{p}>0.05$. This indicates that there is no difference in psychological well-being among Christian youths in the North Sumatra region based on praying every day on the pre-test and on the post-test. Complete data regarding different psychological well-being tests based on daily prayer can be seen in table 25 .

Table 25. PWB Based on Praying Daily

\begin{tabular}{|l|c|c|c|c|}
\hline & F & P & t & p \\
\hline Pre-Test & - & - & 0.349 & 0.728 \\
\hline Post-Test & - & - & 0.274 & 0.785 \\
\hline
\end{tabular}

In Levene's test for equality of variances, it appears that the pre-test data value which refers to the equal variances assumed independent sample $t$-test to find out the similarities or differences in variance between participants who pray every day is $t(-0.436)=0.664 ; \mathrm{p}>0.05$. Meanwhile, the post-test data value which refers to the equal variances assumed independent sample $t$-test to find out the similarities or differences in variance between participants who pray every day is $t(-0.134)=0.894 ; p>0.05$. This shows that there is no difference in forgiveness among Christian youth in the North Sumatra region based on praying every day on the pre-test and post-test. This can be seen in table 26.

Tabel 26. Forgiveness Based on Praying Daily

\begin{tabular}{|l|c|c|c|c|}
\hline & F & P & t & $p$ \\
\hline Pre-Test & - & - & -0.436 & 0.664 \\
\hline Post-Test & - & - & -0.134 & 0.894 \\
\hline
\end{tabular}

\section{Discussion}

Based on the data obtained, the overview of the participants' PWB in the pre-test and post-test did not change; The PWB of the participants were high. However, participants' autonomy decreased on the pre-test and post-test, while their environmental mastery had an 
increase in both pre-test and post-test. As for the other dimensions, PWB did not change and remained high. The high PWB results are in line with the study by Afdal and Ilyas ${ }^{11}$ which showed that the PWB in adolescents was high. In addition, the overview of participant's forgiveness in both pre-test and post-test are high. Likewise, in each dimension, the results of the pre-test and the post-test of forgiveness remained high. These results are in line with research by Supriyadi, Rahman, and Perdini ${ }^{12}$ which shows that forgiveness in adolescents is in the high category. According to Bono, McCullough, and Root in Supriyadi, Rahman, and Perdini ${ }^{11}$, people who have high forgiving behavior will feel calmer because they can be more accepting of conflicts with others.

Tests to see differences between data were carried out, and results show that there were no differences based on participants' gender in the PWB pre-test and post-test data. This result is in line with the study by Afdal and Ilyas ${ }^{13}$ which showed that there was no difference in PWB in male and female. However, there is a difference based on participants' educational background and whether or not the participants read the bible everyday in the PWB post-test data. As for the forgiveness data, results show that there were differences based on educational background and occupation in the pre-test data, while in the post-test data, there is a difference based on how many times an individual reads the bible in a day.

\section{Conclusion}

In conclusion, both pre-test and post-test results of PWB and forgiveness were high while there were differences in each PWB dimension and no difference in each dimension of forgiveness. Results also show that there were differences based on participants' educational background and reading the bible everyday in in the PWB post-test data. As for the forgiveness data, results show that there were differences based on educational background and occupation in the pre-test data, while there is a difference based on the frequency of reading the bible in a day in the post-test data.

${ }^{11}$ Afdal, Afdal, and Asmidir Ilyas. "How psychological well-being of adolescent based on demography indicators?." JPPI (Jurnal Penelitian Pendidikan Indonesia), Vol.6, No.2 (2020): 53-68. https://doi.org/10.29210/02020613.

${ }^{12}$ Supriyadi, Tugimin, Zahra Afifah Rahman, and Tiara Anggita Perdini. "Variabel Forgiveness Ditinjau Dari Religiusitas Pada Remaja." Jurnal Kajian Ilmiah, Vol.21, No.l (2021): 31-44.

${ }^{13}$ Afdal, Afdal, and Asmidir Ilyas. "How psychological well-being of adolescent based on demography indicators?": 53-68. 
The theoretical suggestion is that this research can be continued by looking for the relationship or the impact between the two variables. In addition, the number of samples can be increased, so that the data is more representative of the youth and can also be done in other areas besides North Sumatra. There is a good idea to do a mix method research method, so that in-depth interviews can be conducted to complement the research results.

Then practical advice that can be given is related to the significant results, namely the difference in PWB and forgiveness of participants who read the bible every day. With this, young people should read the Bible every day because it can affect their psychological well-being and forgiveness.

Aknowledgements. We would like to thank LPPM UNTAR and the Faculty of Psychology, who has provided support. We would also like to thank Mrs. Hebat Saing from Huria Kristen Batak Protestan (HKBP) Sigompul who helped us coordinated the process of retrieving data.

\section{Bibliography}

Afdal, Afdal, and Asmidir Ilyas. "How psychological well-being of adolescent based on demography indicators?." JPPI (Jurnal Penelitian Pendidikan Indonesia) 6.2 (2020): 53-68. https://doi.org/10.29210/02020613

Bono, Giacomo, Michael. E. McCullough, \& Lindsay. M. Root. "Forgiveness, Feeling Connected to Others, and Well-Being: Two longitudinal Studies." Personality and Social Psychology Bulletin, Vol.34, No.2 (2008): 182-195. https://doi.org/10.1177/0146167207310025

Jap, Tjibeng, Sri Tiatri, Edo Sebastian Jaya, \& Mekar Sari Suteja. "The Development of Indonesian Online Game Addiction Questionnaire.” Plos One, Vol.8, No.4 (2013): 1-5. https://doi.org/10.1371/journal.pone.0061098.

Juwita, Vita Ratna, \& Erin Ratna Kustanti. "Hubungan antara Pemaafan dengan Kesejahteraan Psikologis pada Korban Perundungan." Jurnal Empati, Vol.7, No.l (2018): 274-282. https:/ejournal3.undip.ac.id/index.php/empati/article/view/20196.

McCullough, M. E. \& W.T. Hoyt. "Transgression-Related Motivational Dispositions: Personality substrates of forgiveness and their links to the big five". Personality and Social Psychology Bulletin, No.28 (2002): 1556-1573. https://doi/10.1177/014616702237583. 
McCullough, E. Michael, \& Giacomo Bono. "Positive Responses to Benefit and Harm: Bringing Forgiveness and Gratitude into Cognitive Psychotherapy." Journal of Cognitive Psychotherapy: An International Quarterly, Vol.20, No.2, (2006): 1-10. https://doi.org/ 10.1891/088983906780639835.

Parasian, Siregar Jundo. “Pengembangan Watak Kristen Melalui Pengampunan”. Jurnal Teologi dan Pendidikan Kristen, No.1 (2020) 33-42. https://doi.org/10.46305/im.vlil.5.

Raudatussalamah \& Reni Susanti. "Pemaafan (forgiveness) dan Psychological Wellbeing pada Narapidana Wanita." Marwah, Vol.8, No.2 (2014): 219 - 234. http://dx.doi.org/10.24014/ marwah.vl3i2.890.

Ryff, Carol Diane, \& Corey Lee M. Keyes. "The Structure of Psychological Well-being Revisited." Journal of Personality and Social Psychology, Vol.64, No.4 (1995): 719-727. https://doi/10.1037/0022-3514.69.4.719.

Ryff, Carol Diane "Psychological Well-being in Adult Life." Current Directions in Psychological Science, Vol.4, No.4 (1995): 99-104. https://doi.org/10.1111\%2F1467-8721.ep10772395.

Ryff, Carol Diane. "Psychological Well-being Revisited: Advances in the Science and Practice of Eudaimonia." Psychotherapy and Psychosomatics, Vol.83 (2014): 10-28. https://doi.org/10.1159/000353263.

Supriyadi, Tugimin, Zahra Afifah Rahman, \& Tiara Anggita Perdini. "Variabel Forgiveness Ditinjau Dari Religiusitas Pada Remaja." Jurnal Kajian Ilmiah, Vol.21, No.l (2021): 31-44.

Wahyuni, Sri \& Yan Kristianus Kadang. "Mendidik Anak (Educating Children)”. QUAERENS: Journal of Theology and Christianity Studies, Vol.1, No.2 (December 2, 2019): 122-143. Accessed October 9, 2021. https://https://doi.org/10.46362/quaerens.vli2.6.

Widjaja, Imron \& Lasmaria Nami Simanungkalit."Christian Religious Education Management, Government Service, In Cell Groups on The Quality of The Faith of Church Members In Indonesia Bethel Church Of Graha Pena." MAHABBAH: Journal of Religion and Education, Vol.1, No.l (2020): 55-69. 10.47135/mahabbah.vli1.8.

Worthington, Everet L., Charlotte van Oyen Witvliet, Pietro Pietrini, \& Andrea J. Miller. "Forgiveness, Health, and Well-being: A Review of Evidence for Emotional versus Decisional Forgiveness, Dispositional Forgivingness, and Reduced Unforgiveness." 
Journal of Behavioral Medicine, Vol.30, No.4 (2007): 291-302. https://doi.org/10.1007/s10865007-9105-8. 